\title{
Perbedaan Derajat Ansietas antara Penyandang Hipertensi Belum Terkontrol dengan yang Terkontrol
}

\author{
${ }^{1}$ Cerelia E. C. Sugeng \\ ${ }^{2}$ Emma Sy. Moeis \\ ${ }^{3}$ Glady I. Rambert
}

\author{
${ }^{1}$ Bagian Ilmu Penyakit Dalam Fakultas Kedokteran Universitas Sam Ratulangi Manado \\ ${ }^{2}$ Divisi Ginjal dan Hipertensi Bagian Ilmu Penyakit Dalam Fakultas Kedokteran \\ Universitas Sam Ratulangi Manado \\ ${ }^{3}$ Bagian Patologi Klinik Fakultas Kedokteran Universitas Sam Ratulangi Manado \\ Email: cereliasugeng@yahoo.com
}

\begin{abstract}
Hypertension and anxiety are among the group of the most common chronic disease worldwide, and according to numerous studies they are oftentimes associated each other. Patients suffered from chronic illnesses, such as hypertension, may have negative emotion that increases the risk of mental disorders, most commonly anxiety disorder. This study was aimed to assess the difference of anxiety degree between uncontrolled and controlled hypertensive patients. This was an observational analytical study with a cross-sectional design. Subjects were divided into two groups: controlled and uncontrolled hypertensive patients. Measurement of blood pressure parameter was performed by using office blood pressure monitoring. Anxiety parameter was classified based on the scoring of the Generalized Anxiety Disorder Scale (GAD-7). Data were analyzed by using the Mann-Whitney test. Subjects consisted of 60 hypertensive patients (35 males and 25 females), aged 30-70 years (mean 56.48 years). There were 35 controlled hypertension patients and 22 uncontrolled hypertensive patients. The results showed that the difference in anxiety degree based on GAD-7 between controlled hypertensive and uncontrolled hypertensive groups obtained a p-value of 0.000 . In conclusion, there was a significant difference in anxiety degree between uncontrolled and controlled hypertensive patients. Screening for anxiety among hypertensive patients is a simple and cost-effective tool that may improve outcomes.
\end{abstract}

Keywords: anxiety, uncontrolled hypertension, controlled hypertension

\begin{abstract}
Abstrak: Hipertensi dan ansietas merupakan kelompok penyakit kronik yang paling umum di seluruh dunia. Berdasarkan banyak penelitian kedua penyakit ini saling berhubungan satu sama lain. Penyandang hipertensi mungkin memiliki emosi negatif yang meningkatkan risiko terjadinya gangguan mental berupa ansietas. Ansietas dan dukungan sosial rendah akan menghambat proses penyembuhan terutama dalam mengontrol tekanan darah. Penelitian ini bertujuan untuk mengetahui apakah terdapat perbedaan derajat ansietas antara penyandang hipertensi belum terkontrol dengan hipertensi terkontrol. Jenis penelitian ialah analitik observasional dengan desain potong lintang. Subyek penelitian dibagi menjadi dua kelompok, yaitu kelompok penyandang hipertensi belum terkontrol dan hipertensi terkontrol. Pengukuran parameter tekanan darah dilakukan dengan menggunakan alat Oscillometric digital dengan cara Office Blood Pressure Monitoring (OBPM). Parameter ansietas diklasifikasikan berdasarkan skala Generalized Anxiety Disorder Scale (GAD7). Adanya perbedaan derajat ansietas antara kedua kelompok dinilai dengan uji Mann-Whitney. Subyek penelitian terdiri dari 60 penyandang hipertensi (35 laki-laki dan 25 perempuan) berusia 30-70 tahun (rerata 56,48 tahun). Terdapat 25 penyandang hipertensi yang belum terkontrol dan 35 penyandang hipertensi terkontrol. Hasil penelitian menunjukkan bahwa terdapat perbedaan derajat ansietas berdasarkan GAD-7 antara kedua kelompok $(\mathrm{p}=0,000)$. Simpulan penelitian ini ialah terdapat perbedaan bermakna dalam derajat ansietas antara penyandang hipertensi yang belum terkontrol dengan yang terkontrol. Skrining ansietas pada penyandang hipertensi merupakan modalitas penting dalam penatalaksanaan penyandang hipertensi.
\end{abstract}

Kata kunci: ansietas, hipertensi belum terkontrol, hipertensi terkontrol 
Peningkatan tekanan darah (hipertensi) dan gangguan kecemasan (ansietas) termasuk salah satu kelompok penyakit kronik yang paling umum ditemukan di seluruh dunia. Kedua penyakit ini sering berkaitan. Pasien penyakit kronik misalnya hipertensi, dapat mengalami emosi negatif yang meningkatkan risiko gangguan mental, yang tersering ialah ansietas. ${ }^{1}$ Berdasarkan penelitian World Health Organization (WHO) tahun 2012, yang dilakukan pada 17 negara, didapatkan satu dari setiap 20 orang hipertensi mengalami episode ansietas di masa lalu. Ansietas memengaruhi sekitar 350 juta orang di seluruh dunia dan berdasarkan survei epidemiologi diperkirakan $1 / 3$ populasi pernah mengalami ansietas sepanjang hidupnya, dengan prevalensi paling sering pada perempuan. ${ }^{2,3}$

Hipertensi merupakan penyakit degeneratif yang menjadi masalah global, karena prevalensinya yang terus meningkat. Diperkirakan pada tahun 2025 sekitar 29\% orang dewasa di seluruh dunia akan menyandang hipertensi. Prevalensi hipertensi secara global tahun 2014 pada kelompok usia di atas 18 tahun sekitar $22 \%$, hampir 1 milyar orang di seluruh dunia menyandang hipertensi. Penyebab kematian akibat komplikasi hipertensi mencapai 9,4 juta kematian dari 17 juta kematian akibat penyakit kardiovaskular per tahun. Hipertensi bertanggung jawab untuk setidaknya $45 \%$ kematian karena penyakit jantung dan $51 \%$ kematian akibat stroke. Diperkirakan pada tahun 2025 peningkatan menjadi sekitar 1,56 milyar orang dewasa akan hidup dengan hipertensi (WHO 2014). ${ }^{4}$

Berdasarkan data American Heart Association (AHA) tahun 2011, dari 59\% penyandang hipertensi hanya $34 \%$ yang terkontrol. Di Indonesia, data Riset Kesehatan Dasar (Riskesdas) tahun 2013, melaporkan prevalensi hipertensi pada penduduk usia 18 tahun keatas sebesar 25,8\%, hanya $1 / 3$ bagian yang terdiagnosis sedangkan sisanya $2 / 3$ bagian tidak terdiagnosis. ${ }^{5}$ Dari 15 juta penyandang hipertensi, 50\% ialah hipertensi belum terkontrol. Menurut Riskesdas tahun 2018, prevalensi hipertensi berdasarkan diagnosis oleh dokter pada penduduk usia $\geq 18$ tahun, ialah $34,1 \%$, dan prevalensi tertinggi didapatkan di Provinsi Sulawesi Utara sebesar $13,2 \%$. $^{5}$

Individu yang didiagnosis hipertensi dapat memiliki keluhan somatik, kualitas hidup yang buruk, dan gangguan dalam fungsi sehari-hari. ${ }^{6,7}$ Faktor-faktor ini berpeluang menyebabkan gangguan psikososial, yang meningkatkan risiko terjadinya ansietas. Beberapa penelitian (Phofl et al, Patten et al, Markovitz et al, Nicholson et al) ${ }^{8}$ menunjukkan bahwa individu yang mengalami ansietas berisiko tinggi untuk menyandang hipertensi, serta menjadi rentan untuk terjadinya stroke, penyakit jantung iskemik, dan bahkan kematian. Berdasarkan hasil penelitian meta analisis yang dilakukan Zhanzhan et al (2015), dengan total populasi 30.796 penyandang hipertensi, didapatkan prevalensi ansietas sebesar 29,8\%; artinya sekitar 9.177 penyandang hipertensi mengalami ansietas. ${ }^{2}$ Penyandang hipertensi yang mengalami ansietas dan memiliki dukungan sosial rendah akan terhambat proses penyembuhan terutama dalam mengontrol tekanan darah. Oleh karena itu, sangat penting dipertimbangkan gejala ansietas dan dukungan sosial selama proses pencegahan dan pengobatan hipertensi. Diperlukan intervensi efektif untuk ansietas dan dukungan sosial yang berpusat pada pasien. ${ }^{2}$

Berdasarkan latar belakang di atas, maka dilakukan penelitian ini untuk mengetahui apakah terdapat perbedaan antara derajat ansietas pada penyandang hipertensi belum terkontrol dengan hipertensi yang terkontrol.

\section{METODE PENELITIAN}

Penelitian ini dilaksanakan di Poliklinik Rawat Jalan Ginjal-Hipertensi RSUP Prof. Dr. R. D. Kandou Manado, pada bulan April-September 2019. Jenis penelitian ialah observasional analitik dengan desain potong lintang.

Populasi penelitian ialah penyandang hipertensi yang berobat di Poliklinik Rawat Jalan Ginjal Hipertensi RSUP Prof. Dr. R. D. Kandou Manado dalam selang waktu 
tersebut. Besar sampel yang dibutuhkan dalam penelitian ini diperoleh dengan menggunakan rumus analitik numerik dengan hasil sampel minimal sebesar 38 orang. Sampel dipilih secara consecutive sampling serta memenuhi kriteria penelitian, dan dibagi atas dua kelompok, yaitu: kelompok hipertensi belum terkontrol (TD $\geq 140 / 90 \mathrm{mmHg}$, dengan terapi obat anti hipertensi (OAH) minimal 1 jenis selama 6 bulan) dan kelompok hipertensi terkontrol ( $\mathrm{TD} \leq 140 / 90 \mathrm{mmHg}$, dengan terapi OAH minimal 1 jenis selama 6 bulan). Obat anti hipertensi yang dikonsumsi termasuk golongan diuretik, calcium-channel blockers (CCB), angiotensin converting enzyme inhibitor (ACE-I), angiotensin receptor blockers (ARBs), $\beta$-blocker, dan vasodilator sentral. Penyandang hipertensi yang tidak patuh minum obat anti hipertensi, hipertensi sekunder, demensia, dan pasien dengan penurunan kesadaran tidak diikutsertakan dalam penelitian ini.

Generalized Anxiety Disorder-7 (GAD7) adalah kuesioner skrining ansietas yang terdiri dari tujuh pertanyaan, dengan skor mulai dari 0 hingga 21. Skor GAD-7 mengklasifikasikan ansietas menjadi empat derajat, yaitu: skor 0-5: ansietas ringan; skor 6-10: ansietas sedang; skor 11-15: ansietas berat; dan skor $\geq 16$ : ansietas sangat berat.

Setelah menandatangani informed consent semua subyek penelitian menjalani proses pemeriksaan secara anamnesis dan pemeriksaan fisik standar, pengukuran tekanan darah dengan cara Office Blood Pressure Monitoring (OBPM), dan melakukan pengisian kuesioner GAD-7.

Data yang diperoleh dianalisis dengan menggunakan program melalui perangkat komputer. Uji statistik yang digunakan ialah uji deskriptif secara umum dengan metode univariat dan uji One sample Kolmogrov-Sminov untuk mendapatkan nilai minimum, maksimum, rerata, standar deviasi serta distribusi normal dari seluruh variabel penelitian. Uji Mann-Whitney U dilakukan untuk menilai adanya perbedaan derajat ansietas antara kelompok hipertensi belum terkontrol dan hipertensi terkontrol. Batas kemaknaan yang digunakan ialah $95 \%(\alpha=0,05)$. Hasil penelitian dinarasikan dan diperjelas dengan tabel dan grafik.

\section{HASIL PENELITAN}

Pada penelitian ini didapatkan 60 penyandang hipertensi yang memenuhi kriteria inklusi dan ekslusi, terdiri dari 25 perempuan dan 35 laki-laki. Usia subyek penelitian ialah 30-70 tahun dengan rerata 56,48 tahun. Karakteristik pasien dapat dilihat pada Tabel 1.

Tabel 2 memperlihatkan hasil uji Mann Whitney tidak berpasangan antara nilai skor GAD-7 pada subyek hipertensi belum terkontrol dan hipertensi terkontrol. Berdasarkan uji Mann-Whitney, terdapat perbedaan bermakna antara skor GAD-7 pada kelompok hipertensi belum terkontrol dengan kelompok hipertensi terkontrol dengan nilai $\mathrm{p}=0,000(\mathrm{p}<0,05)$.

\section{BAHASAN}

Pada penelitian ini, terdapat 60 pasien yang telah terdiagnosis hipertensi oleh klinisi sebelumnya dengan jumlah subyek laki-laki lebih banyak daripada perempuan. Hal ini sesuai dengan pernyataan bahwa prevalensi hipertensi memang didapatkan lebih tinggi pada jenis kelamin laki-laki dibandingkan perempuan.?

Skor GAD-7 yang didapat dari hasil penelitian ini memiliki rerata $3,47 \pm 0,45$. Pada penelitian ini juga didapatkan 35

Tabel 1. Karakteristik subyek penelitian

\begin{tabular}{lcccccc}
\hline \multicolumn{1}{c}{ Variabel } & N & Min & Maks & Median & Rerata & SB \\
\hline Usia & 60 & 33 & 70 & 59,5 & 56,48 & 1,41 \\
GAD-7 & 60 & 1 & 20 & 2 & 3,47 & 0,45 \\
TDS & 60 & 94 & 180 & & 130,07 & 2,76 \\
TDD & 60 & 40 & 100 & & 71,83 & 1,70 \\
\hline
\end{tabular}

Ket: TDS, tekanan darah sistolik; TDD, tekanan darah diastolik 
Tabel 2. Perbedaan nilai skor GAD-7 antara kelompok hipertensi belum terkontrol dengan hipertensi terkontrol

\begin{tabular}{cccccc}
\hline Variabel & Group Hipertensi & n & Rerata & SB & p \\
\hline Skor GAD-7 & Belum terkontrol & 25 & 41,82 & 1045,5 & 0,000 \\
& Terkontrol & 35 & 22,41 & 784,5 & \\
\hline
\end{tabular}

Keterangan: Uji Mann Whitney

pasien masuk dalam kelompok hipertensi terkontrol; sisanya 25 pasien masuk dalam kelompok hipertensi belum terkontrol.

Uji statistik yang digunakan pada penelitian ini ialah uji Mann-Whitney untuk mencari apakah terdapat perbedaan antara skor GAD-7 pada kelompok hipertensi yang belum terkontrol dan hipertensi yang terkontrol, Hasil uji Mann Whitney menunjukkan bahwa penyandang hipertensi belum terkontrol cenderung untuk terjadi ansietas lebih tinggi dibandingkan penyandang hipertensi terkontrol. Mekanisme yang mungkin mendasari kejadian tersebut yaitu pada penyandang hipertensi dengan ansietas mengalami peningkatan aktivitas simpatis serta peningkatan sekresi hormon adrenokortikotropik dan kortisol. Oleh karena itu secara patofisiologi, ansietas dan hipertensi akan saling memengaruhi. Hal ini sesuai dengan penelitian oleh Grimsuld et $\mathrm{al}^{9}$ yang melaporkan adanya hubungan bermakna antara hipertensi dengan ansietas pada 4351 orang dewasa muda dengan rerata usia 37 tahun.

Penyandang hipertensi dengan ansietas menunjukkan peningkatan aktivitas simpatis dan penurunan aktivitas parasimpatis, yang tidak hanya berkontribusi pada peningkatan dan kontrol yang buruk dari tekanan darah, tetapi juga dapat meningkatkan risiko aritmia jantung. Karena ansietas dan hipertensi memiliki jalur yang sama, maka berpeluang didapatkan ansietas pada penyandang hipertensi dan hipertensi pada ansietas. Selain itu, penyandang hipertensi yang mengalami ansietas mungkin memiliki kontrol tekanan darah yang buruk. ${ }^{10}$

\section{SIMPULAN}

Berdasarkan hasil penelitian ini dapat disimpulkan bahwa terdapat perbedaan derajat ansietas pada penyandang hipertensi belum terkontrol dengan hipertensi terkontrol. Penyandang hipertensi belum terkontrol memiliki derajat ansietas yang lebih tinggi, yang ditandai dengan rerata skor GAD-7 yang lebih tinggi pula.

\section{DAFTAR PUSTAKA}

1. DeJean D, Giacomini M, Vanstone $M$, Brundisini F. Patient experiences of depression and anxiety with chronic disease: a systematic review and quantitative meta-synthesis. Ont Health Techol Assess Ser. 2013;13(16):1-33.

2. Li Z, Li Y, Chen L, Chen P, Hu Y. Prevalence of depression in patients with hypertension: a systematic review and meta-analysis. Medicine. 2015; 94(31):e1317. Doi:10.1097/MD. 0000 000000001317

3. Bandelow B. Epidemiology of anxiety disorders in the 21st. Dialogues Clinical Neuroscience. 2015;17(3):327-35

4. World Health Organization, Global Status Report on non-communicable diseases, 2014. Available from: http://apps.who. int/iris/bitstream/handle/10665/148114/ 9789241564854_eng.pdf;jsessionid $=\mathrm{C}$ CFDDE3A3A33BA7680524AEA9FC C3707? sequence $=1$

5. Badan Penelitian dan Pengembangan Kesehatan Kementerian Kesehatan Republik Indonesia. Riset Kesehatan Dasar (Riskesdas) Tahun 2013; p. 98. Available from: http://www.depkes. go.id/resources/download/general/Hasil \%20Riskesdas\%202013.pdf

6. Almas A, Patel J, Ghori U, Ali A, Edhi Al, Khan MA. Depression is linked to uncontrolled hypertension: a casecontrol study from Karachi, Pakistan. J Ment Health. 2014;23(6):292-6.

7. Kretchy IA, Owusu-Daaku FT, Danquah SA. Mental health in hypertension: assessing symptoms of anxiety depresssion and stress on anti-hypertensive medication adherence. Int $\mathbf{J}$ Ment 
112 Jurnal e-Clinic (eCl), Volume 7, Nomor 2, Juli-Desember 2019

Health Syst. 2014;8:25.

8. Meng L, Chen D, Yang Y, Zheng Y, Hui R. Depression increases the risk of hypertension incidence: A metaanalysis of prospective cohort studies. J Hypertens. 2012;30:842-51.

9. Grimsrud A, Stein DJ, Seedat S, Williams D, Myer L. The association between hypertension and depression and anxiety disorders: results from a nationally-representative sample of South African adults. PloSOne. 2009; 4:e5552.

10. Kaplan NM. Clinical Hypertension (9th ed). Philadelphia: Lippincott Williams \& Wilkins, 2006; p. 52-3 